Sains Malaysiana 46(8)(2017): 1211-1219

http://dx.doi.org/10.17576/jsm-2017-4608-06

\title{
Penentuan Kualiti Air daripada Sistem Penuaian Air Hujan di Kolej Ungku Omar, UKM Bangi
}

(Determination of Rainwater Quality from Rainwater Harvesting System at Ungku Omar College, UKM Bangi)

\author{
Nur Syarina ASMan, AZHAR AbDUl Halim, Marlia MoHd HANAFIAH \& FARAH DiYANA ARIFFin*
}

\begin{abstract}
ABSTRAK
Kajian ini bertujuan untuk menentukan tahap kualiti air hujan di dalam Sistem Penuaian Air Hujan iaitu MyRAWAS yang dibina di Kolej Kediaman Ungku Omar, UKM, Bangi. Parameter air hujan yang dikaji dibandingkan dengan Piawai Kualiti Air Kebangsaan Malaysia (NWQS) dan Piawai Kualiti Air Minum. Parameter yang diuji dalam analisis air hujan ialah suhu, $\mathrm{pH}$, kekeruhan, jumlah pepejal terampai (TSS), oksigen terlarut (DO), permintaan oksigen biokimia $(B O D)$, permintaan oksigen kimia (COD), ammonia-nitrogen $\left(\mathrm{NH}_{3}-\mathrm{N}\right)$, Koliform Jumlah dan Escherichia coli. Hasil kajian mendapati bahawa kesemua bacaan parameter mematuhi piawaian yang telah ditetapkan oleh Piawai Kualiti Air Kebangsaan Malaysia (NWQS) dan Piawai Air Minum Kebangsaan dengan purata nilai suhu, pH, kekeruhan, TSS, $\mathrm{DO}, \mathrm{BOD}$, COD dan $\mathrm{NH}_{3}-\mathrm{N}$ masing-masing berada pada julat $26.2^{\circ} \mathrm{C}-28.6^{\circ} \mathrm{C}, 6.18-6.36,0.93-3.06 \mathrm{ntu}, 1.0-4.6 \mathrm{mg} / \mathrm{L}$, 6.21-8.29 mg/L, 0.21-0.43 mg/L, 3-7 mg/L dan 0.01-0.47 mg/L. Manakala bacaan Koliform Jumlah dan Escherichia coli berada di bawah had maksimum yang ditetapkan oleh Piawai Kualiti Air Minum. Berdasarkan Indeks Kualiti Air (IKA), kualiti air hujan di kawasan kajian berada pada kelas IIA bagi titik persampelan T1 dan T2 dan berubah menjadi kelas I selepas menjalani kaedah rawatan penapisan iaitu pada titik persampelan T3. Hasil kajian ini juga mendapati bahawa air tuaian hujan tersebut selamat untuk digunakan untuk aktiviti harian.
\end{abstract}

Kata kunci: Kolej kediaman; kualiti air; Malaysia; MyRAWAS; sistem penuaian air hujan

\section{ABSTRACT}

The aim of this study was to determine the water quality level of Rainwater Harvesting System (MyRAWAS) built at Ungku Omar Residential College, UKM, Bangi. The parameters analysed were compared with the National Water Quality Standards Malaysia (NWQS) and Drinking Water Quality Standards. The parameters that were tested in the analysis of rainwater were temperature, $p H$, turbidity, total suspended solid (TSS), dissolved oxygen (DO), biological oxygen demand $(B O D)$, chemical oygen demand (COD), ammoniacal nitrogen $\left(\mathrm{NH}_{3}-\mathrm{N}\right)$, Total Coliforms and Escherichia coli. The study showed that all parameters conform to the standard set by National Water Quality Standards Malaysia (NWQS) and Drinking Water Quality Standards. The results showed that temperature, $\mathrm{pH}$, turbidity, TSS, DO, BOD, COD and NH $-\mathrm{N}$ mean values are $26.2^{\circ} \mathrm{C}-28.6^{\circ} \mathrm{C}, 6.18-6.36,0.93-3.06 \mathrm{ntu}, 1.0-4.6 \mathrm{mg} / \mathrm{L}, 6.21-8.29 \mathrm{mg} / \mathrm{L}, 0.21-0.43 \mathrm{mg} / \mathrm{L}, 3-7 \mathrm{mg} / \mathrm{L}$ and $0.01-0.47 \mathrm{mg} / \mathrm{L}$, respectively. Meanwhile the Total Coliform and Escherichia coli are below the maximum limit set by the Drinking Water Quality Standards. According to the Water Quality Index (IKA), the quality of rainwater in the study area is in class IIA for sampling point T1 and T2 and turned into class I after undergoing filtration treatment at sampling point T3. The result showed that the rainwater is safe to be used for their daily activities.

Keywords: Malaysia; MyRAWAS; rainwater harvesting system; residential college; water quality

\section{PENGENALAN}

Krisis air adalah salah satu daripada isu penting yang dihadapi pada peringkat global pada masa kini. Hal ini disebabkan oleh arus pemodenan yang berlaku bagi meningkatkan taraf hidup manusia di sesebuah negara. Proses ini akan memberi tekanan kepada pihak kerajaan bagi memenuhi permintaan air bersih daripada pelbagai pihak (United Nations World Water Assessment Programme (WWAP) 2015). Menurut World Health Organization (WHO)/ United Nations Children's Fund (UNICEF) (2014), seramai 750 juta penduduk di seluruh dunia mengalami masalah dalam mendapatkan bekalan air yang bersih dan selamat.
Malah, terdapat sesetengah kawasan yang mengalami masalah sumber bekalan air yang terhad.

Di Malaysia, pelbagai teknologi bekalan air berkos rendah telah dibangunkan untuk memberi bekalan air selamat kepada pengguna seperti sistem air graviti, sistem bekalan air perigi dan sistem penuaian air hujan (Yaziz et al. 1989). Sistem penuaian air hujan digunakan apabila tiada bekalan air alternatif yang sesuai boleh didapati (Gikas \& Tsihrintzis 2012). Penggunaan Sistem Penuaian Air Hujan (SPAH) telah menjadi salah satu langkah dalam mengatasi permintaan air bersih (Lee et al. 2016). Sistem ini mempunyai beberapa komponen asas iaitu tadahan 
bumbung, sistem perpaipan, tangki pengumpulan dan tangki simpanan.

Satu inisiatif telah diambil oleh penyelidik daripada Pusat Pengajian Sains Sekitaran dan Sumber Alam, Fakulti Sains Teknologi UKM untuk memperkenalkan SPAH yang diberi nama MyRAWAS di kolej kediaman pelajar iaitu Kolej Ungku Omar (KUO) yang terletak di Universiti Kebangsaan Malaysia (UKM), Bangi. Pemilihan KUO adalah kerana kolej ini yang paling terjejas apabila berlakunya krisis dan catuan bekalan air terutamanya semasa musim kemarau dan berlaku kontaminasi di kawasan tadahan air. Kadar air masuk dan paras air di dalam tangki simpanan UKM pada tarikh 20 Mac 2015 ialah pada julat $0 \mathrm{~m}^{3} / \mathrm{h}-3.2 \mathrm{~m}^{3} / \mathrm{h}$. Oleh itu, ia merupakan salah satu faktor berlakunya krisis air di KUO.

Secara amnya, air hujan adalah selamat untuk kegunaan domestik jika ia dikumpul dengan teliti. Walau bagaimanapun, kualiti air hujan boleh dipengaruhi oleh bahan pencemar udara, ciri atap serta najis serangga, burung dan haiwan kecil (Achadu et al. 2013; Yaziz et al. 1989). Oleh itu, pengguna yang terlibat dalam penggunaan SPAH hendaklah sedar akan kesan terhadap kesihatan akibat daripada pencemaran fizikal, kimia serta mikrobiologi di dalam air larian yang dikumpulkan oleh SPAH dan mengambil langkah yang sesuai untuk mengelakkan daripada menggunakan air tercemar.

Sehubungan itu, kajian ini dijalankan bagi menentukan Indeks Kualiti Air (IKA) air hujan yang dikumpulkan melalui atap bumbung di KUO, UKM yang melibatkan persampelan di tiga bahagian iaitu, air hujan terawal, T1 (pelencong pancur pertama), air hujan daripada tangki pengumpulan, T2 (tangki pengumpulan) dan air hujan daripada tangki penyimpanan, T3 (tangki simpanan) selepas melalui rawatan tapisan batu kerikil dan tapisan karbon teraktif. Parameter yang terlibat dalam kajian ini adalah parameter fiziko-kimia dan mikrobiologi yang hadir di dalam sistem MyrawAS di Kolej Kediaman Ungku Omar, UKM, Bangi.

\section{BAHAN DAN KAEDAH}

\section{KAWASAN KAJIAN}

Kawasan kajian yang dipilih terletak di blok K8K dan K8M pangsasiswa Kolej Ungku Omar, UKM Kampus Bangi. Kawasan kajian ini mempunyai kawasan lapangan yang luas dan menjadikan tempat tersebut sesuai bagi proses penuaian air hujan. Bangunan tersebut berada pada kawasan paling belakang di dalam kawasan kolej. Justeru, tiada pokok yang ditanam pada kawasan sistem penuaian air hujan ini bagi mengelakkan berlakunya daundaun kering jatuh di atas bumbung dan akan mengganggu kualiti air tersebut.

Rajah 1 menunjukkan sistem MyRAWAS yang direka bentuk dan dibina di kawasan kajian iaitu di KUO, UKM, manakala Rajah 2 pula menunjukkan rajah skematik bagi sistem MyRAWAS.

\section{PERSAMPELAN DI LAPANGAN DAN ANALISIS MAKMAL}

Sebanyak lima kali persampelan air hujan telah dijalankan daripada bulan November 2015 sehingga bulan Januari 2016 iaitu selama tiga bulan di KUO, UKM Bangi. Terdapat tiga titik persampelan yang telah ditetapkan iaitu air hujan terawal (T1), air hujan daripada tangki pengumpulan (T2) dan air hujan daripada tangki penyimpanan (T3).

Alatan yang digunakan bagi analisis in situ dikalibrasi terlebih dahulu sebelum digunakan seperti meter kekeruhan, meter $\mathrm{pH}$, meter suhu dan meter YSI oksigen terlarut. Bagi parameter mikrobiologi pula, botol atau alat radas telah disterilkan dengan menggunakan $70 \%$ alkohol

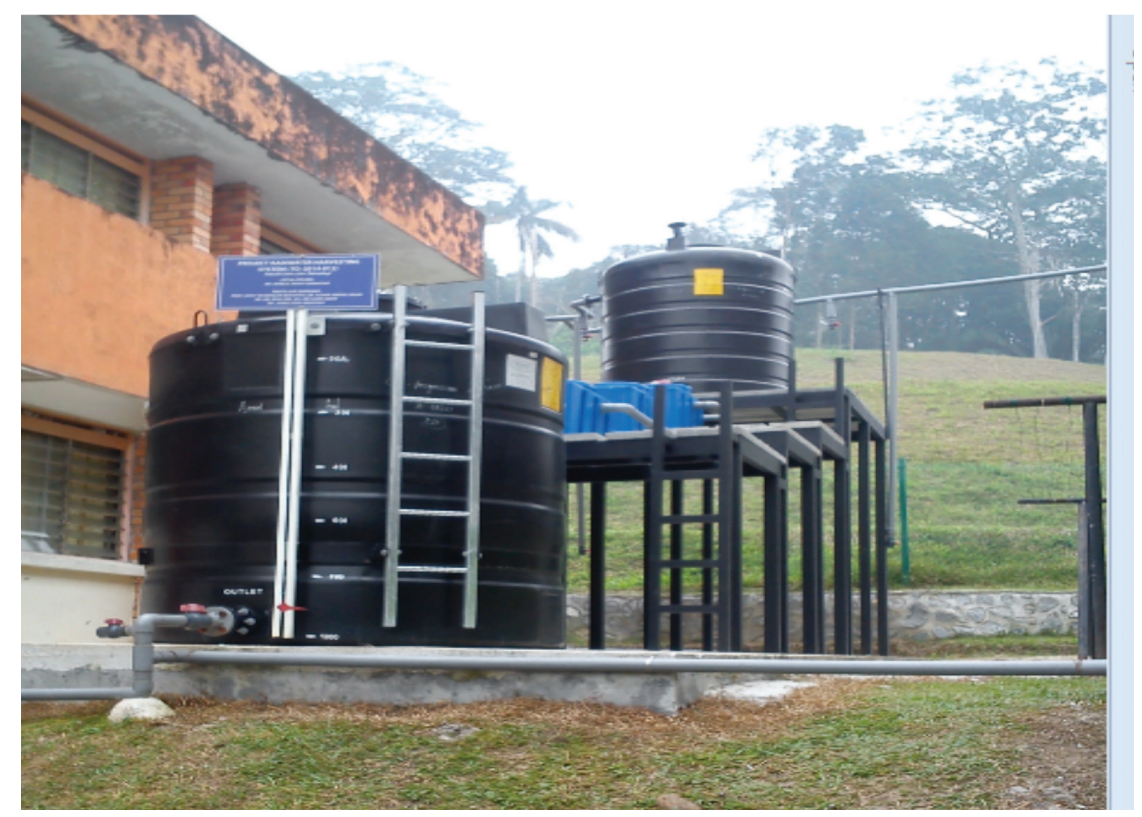

RAJAH 1. Sistem Penuaian Air Hujan MyRAWAS di KUO, UKM 


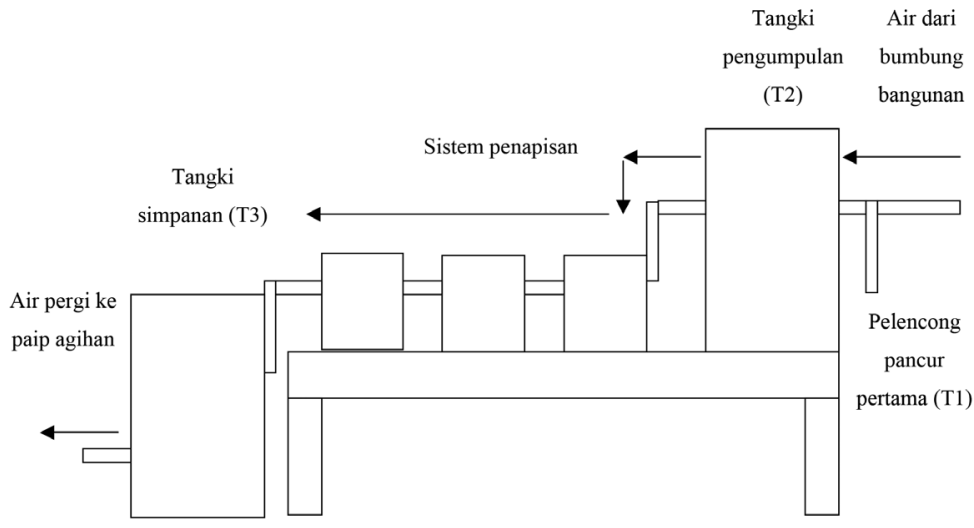

RAJAH 2. Diagram skematik bagi sistem MyRAWAS

untuk mengelakkan kontaminasi mikrob. Pengawetan sampel untuk parameter permintaan oksigen kimia (COD) dan ammonia-nitrogen $\left(\mathrm{NH}_{3}-\mathrm{N}\right)$ dilakukan dengan menambahkan larutan asid sulfurik $99 \%$ ke dalam sampel sehingga $\mathrm{pH}$ sampel mencapai $\mathrm{pH} 2$ atau lebih rendah (APHA 1999). Sampel air perlu diawet sehingga mencapai $\mathrm{pH} 2$ untuk mengelakkan biodegrasi dan hidrolisis sebatian kimia (APHA 1999). Manakala bagi sampel permintaan oksigen biokimia (BOD), sampel air disimpan ke dalam bekas Coleman yang berisi ais bagi melambatkan kadar tindak balas pembiakan mikroorganisma.

Sampel air dianalisis bagi sepuluh parameter iaitu $\mathrm{pH}$, suhu, kekeruhan, jumlah pepejal terampai (TSS), oksigen terlarut (DO), BOD, COD, $\mathrm{NH}_{3}-\mathrm{N}$, Koliform Jumlah dan Escherichia coli. Jadual 1 menunjukkan parameter yang terlibat dan kaedah yang digunakan dalam menganalisis sampel air tersebut. Analisis bagi parameter $\mathrm{pH}$, suhu, kekeruhan dan oksigen terlarut dilakukan secara in situ. Manakala bagi parameter yang lain dilakukan secara ex situ (Kasan 2006; Salam \& Mahmood 1988). Bagi parameter BOD, bacaan DO pada hari pertama diambil dan sampel air berkenaan disimpan di dalam inkubator pada suhu $20^{\circ} \mathrm{C}$ selama lima hari (APHA 1999). Pada hari kelima, bacaan DO diambil semula dan pengiraan untuk mendapatkan nilai BOD adalah menggunakan formula di bawah.

$$
\begin{aligned}
\mathrm{BOD}= & \text { DO (bacaan pada hari pertama })- \\
& \text { DO (bacaan pada hari kelima })
\end{aligned}
$$

Hasil daripada analisis sampel air hujan tersebut, pengiraan Indeks Kualiti Air (IKA) digunakan bagi mengetahui kualiti air hujan tersebut sama ada boleh

\begin{tabular}{|c|c|c|}
\hline Parameter & Kaedah Piawaian (APHA 1999) & Alat yang digunakan \\
\hline $\begin{array}{l}\mathrm{pH} \\
\text { Suhu }\end{array}$ & Elektrometrik & $\begin{array}{l}\text { Meter pH (model Hanna HI 8424) } \\
\text { YSI Pro DO meter }\end{array}$ \\
\hline Kekeruhan & Serakan cahaya & Turbidimeter mudah alih (model TB400) \\
\hline $\begin{array}{l}\text { TSS } \\
\text { DO }\end{array}$ & Photometric method (8006 method) & $\begin{array}{l}\text { HACH DREL } 2800 \text { Spectrofotometri } \\
\text { YSI Pro DO meter }\end{array}$ \\
\hline $\begin{array}{l}\text { BOD } \\
\text { COD }\end{array}$ & $\begin{array}{l}\mathrm{BOD}_{5}(\mathrm{APHA} 1999) \\
\text { Kaedah Penghadaman Reaktor } \\
\text { (Method 8000) }\end{array}$ & $\begin{array}{l}\text { Meter Oksigen Terlarut (model YSI 5000) } \\
\text {-HACH DREL } 2800 \\
\text { Spectrofotometri } \\
\text {-Reaktor COD (model } \\
45600 \text { ) }\end{array}$ \\
\hline $\mathrm{NH}_{3}-\mathrm{N}$ & $\begin{array}{l}\text { Kaedah Salicylate bagi julat } 0.01 \text { to } \\
0.50 \mathrm{mg} / \mathrm{L} \mathrm{NH}_{3}-\mathrm{N} \text { (Method } 8155 \text { ) }\end{array}$ & HACH DREL 2800 Spectrofotometri \\
\hline Koliform Jumlah & Kaedah Colilert & $\begin{array}{l}\text { Inkubator Bakteria Thermolyne } \\
\text { Colilert }^{\circledR} / \text { Quanti-Tray }\end{array}$ \\
\hline E. coli & Kaedah Colilert & $\begin{array}{l}\text { Inkubator Bakteria Thermolyne } \\
\text { Colilert }^{\circledR} / \text { Quanti-Tray }{ }^{\circledR} \\
\text { Lampu UV }\end{array}$ \\
\hline
\end{tabular}

JADUAL 1. Kaedah piawaian dan instrumentasi yang digunakan untuk analisis kualiti air hujan 
JADUAL 2. Julat subindeks setiap parameter Indeks Kualiti Air berdasarkan Piawai Kualiti Air Kebangsaan

\begin{tabular}{|c|c|c|c|c|c|c|c|}
\hline \multirow[t]{2}{*}{ Parameter } & \multirow[t]{2}{*}{ Unit } & \multicolumn{6}{|c|}{ Kelas } \\
\hline & & I & IIA & IIB & III & IV & V \\
\hline Oksigen terlarut (DO) & $\mathrm{mg} / \mathrm{L}$ & 7 & $5-7$ & $5-7$ & $3-5$ & $<3$ & $<1$ \\
\hline Permintaan oksigen biokimia (BOD) & $\mathrm{mg} / \mathrm{L}$ & 1 & 3 & 3 & 6 & 12 & $>12$ \\
\hline Permintaan oksigen kimia (COD) & $\mathrm{mg} / \mathrm{L}$ & 10 & 25 & 25 & 50 & 100 & $>100$ \\
\hline Ammonia-nitrogen $\left(\mathrm{NH}_{3}-\mathrm{N}\right)$ & $\mathrm{mg} / \mathrm{L}$ & 0.1 & 0.3 & 0.3 & 0.9 & 2.7 & $>2.7$ \\
\hline Pepejal terampai (SS) & $\mathrm{mg} / \mathrm{L}$ & 25 & 50 & 50 & 150 & 300 & 300 \\
\hline $\mathrm{pH}$ & - & $6.5-8.5$ & $6-9$ & $6-9$ & $5-9$ & $5-9$ & - \\
\hline
\end{tabular}

Sumber: EPA 2008

diminum atau hanya boleh digunakan bagi tujuan domestik yang lain seperti membersih tandas, mencuci kereta dan menyiram pokok. Sebanyak enam parameter diambil kira dalam menentukan nilai IKA iaitu permintaan oksigen biokimia (BOD), permintaan oksigen kimia (COD), oksigen terlarut (DO), ammonia-nitrogen $\left(\mathrm{NH}_{3}-\mathrm{N}\right)$, jumlah pepejal terampai (TSS) dan pH (EPA 2008). Julat nilai subindeks (SI) setiap parameter IKA diberikan dalam Jadual 2. Berikut merupakan formula yang digunakan dalam penentuan IKA.

$$
\begin{aligned}
\mathrm{IKA}= & \left(0.22 \times \mathrm{SI}_{\mathrm{DO}}\right)+\left(0.19 \times \mathrm{SI}_{\mathrm{BOD}}\right)+\left(0.16 \times \mathrm{SI}_{\mathrm{COD}}\right) \\
& +\left(0.15 \times \mathrm{SI}_{\mathrm{AN}}\right)+\left(0.16 \times \mathrm{SI}_{\mathrm{SS}}\right)+\left(0.12 \times \mathrm{SI}_{\mathrm{pH}}\right),
\end{aligned}
$$

dengan $\mathrm{SI}_{\mathrm{DO}}$ ialah sub indeks bagi DO; $\mathrm{SI}_{\mathrm{BOD}}$ ialah sub indeks bagi BOD; $\mathrm{SI}_{\mathrm{COD}}$ ialah sub indeks bagi COD; $\mathrm{SI}_{\mathrm{AN}}$ ialah sub indeks bagi $\mathrm{NH}_{3}-\mathrm{N}$; $\mathrm{SI}_{\mathrm{SS}}$ ialah sub indeks bagi $\mathrm{SS} ; \mathrm{SI}_{\mathrm{pH}}$ ialah sub indeks bagi $\mathrm{pH}$.

\section{ANALISIS STATISTIK}

Analisis statistik dijalankan dengan menggunakan Statistical Package for the Social Sciences (SPSS) versi 22. Semua data bagi parameter fiziko-kimia dalam kajian ini ditunjukkan dalam purata \pm sisihan piawai. Manakala data bagi parameter mikrobiologi direkodkan dalam unit nombor paling barangkali (MPN). Analisis statistik yang digunakan adalah analisis ANOVA bagi membandingkan ciri-ciri fiziko-kimia pada air tuaian hujan antara titik persampelan.

\section{KePUTUSAN DAN PERBINCANGAN}

Rajah 3 menunjukkan nilai purata lima kali persampelan bagi bacaan parameter suhu. Titik persampelan T2 menunjukkan nilai bacaan paling tinggi iaitu $28.6^{\circ} \mathrm{C}$ berbanding pada titik persampelan $\mathrm{T} 1 \mathrm{dan} \mathrm{T} 3$ iaitu masingmasing pada $26.2^{\circ} \mathrm{C}$ dan $27.1^{\circ} \mathrm{C}$. Perbezaan bacaan suhu pada setiap titik persampelan tidak mempunyai perbezaan yang signifikan dan berada pada julat yang normal air di Malaysia iaitu $24^{\circ} \mathrm{C}$ hingga $31^{\circ} \mathrm{C}$.

Nilai $\mathrm{pH}$ merupakan parameter penting bagi mengenal pasti tahap kealkalian atau keasidan air. Menurut Rajah
4, nilai $\mathrm{pH}$ bagi ketiga-tiga titik persampelan adalah tidak berbeza secara signifikan $(p>0.05)$ iaitu masing-masing untuk T1, T2 dan T3 adalah 6.18, 6.26 dan 6.36. Nilai purata tersebut semakin menghampiri $\mathrm{pH}$ neutral iaitu 7 dan berada dalam julat nilai piawaian yang ditetapkan oleh Kementerian Kesihatan Malaysia (KKM) iaitu pada 5.5-9. Air hujan tersebut selamat untuk digunakan dan tidak berbahaya kepada pengguna. Pelajar boleh menggunakan air hujan tersebut untuk kegunaan domestik.

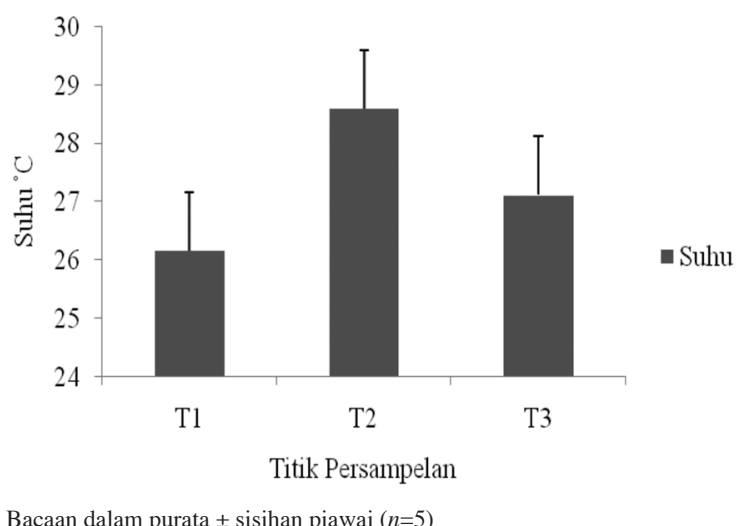

RAJAH 3. Purata nilai suhu bagi tiga titik persampelan

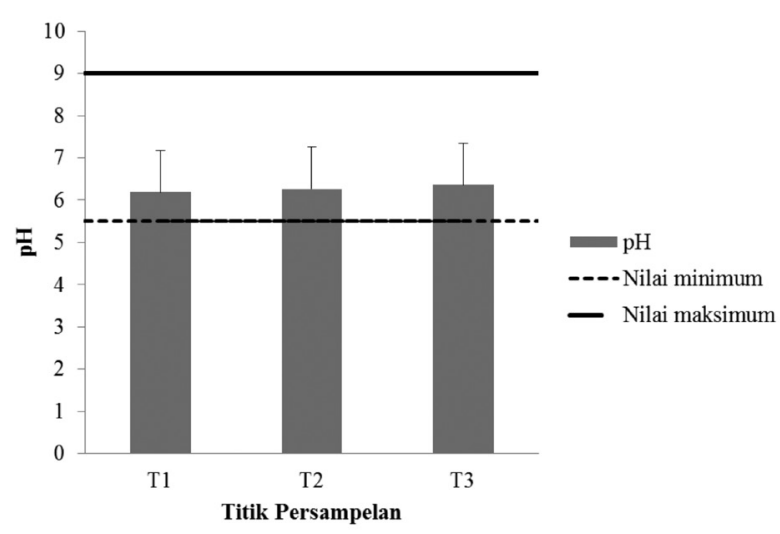

Bacaan dalam purata \pm sisihan piawai $(n=5)$

RAJAH 4. Purata nilai $\mathrm{pH}$ bagi tiga titik persampelan 
Kajian yang dilakukan oleh Seong dan Sapari (2003) menunjukkan air hujan yang dikaji di Semenanjung Malaysia adalah berada pada julat $\mathrm{pH} 4.5-5.6$. Nilai $\mathrm{pH}$ air hujan yang kurang daripada 4.4 memberi indikasi bahawa kawasan persampelan terletak di kawasan perindustrian berat (Seong \& Sapari 2003). Dalam kajian yang dijalankan oleh Thamer et al. (2012) di Serdang, Selangor, didapati purata nilai bacaan $\mathrm{pH}$ air hujan adalah 5.71 dan mencadangkan air tersebut digunakan untuk mandi dan membasuh. Menurut Macomber (2010), sekiranya air hujan tersebut berasid, ia boleh mengundang masalah hakisan kepada Sistem Penuaian Air Hujan terutama kepada tangki simpanan air.

Seterusnya, Rajah 5 pula menunjukkan graf purata bagi parameter jumlah pepejal terampai (TSS) bagi setiap titik persampelan. Kepekatan TSS yang paling tinggi direkodkan pada titik persampelan $\mathrm{T} 1$ dan diikuti dengan titik persampelan T2 dan T3. Walau bagaimanapun, kesemua nilai bacaan berada pada kelas I berdasarkan kepada Piawai Kualiti Air Kebangsaan (NWQS) iaitu kurang daripada 25 $\mathrm{mg} / \mathrm{L}$. Hal ini disebabkan partikel-partikel atau bahan pencemar yang terdapat pada bumbung bangunan seperti debu, habuk, daun kering atau najis burung telah dibawa bersama oleh air hujan terawal yang memasuki T1 iaitu pelencong pancur pertama. Kesan daripada kemasukan air hujan terawal ini menyebabkan bumbung bangunan tersebut dibersihkan dan air hujan yang seterusnya yang mempunyai kurang bahan pencemar akan disimpan ke dalam tangki pengumpulan iaitu T2 sebelum dirawat. Penggunaan pelencong pancur pertama merupakan alat yang sering digunakan bagi mengurangkan penggumpalan bahan pencemar ke dalam tangki penyimpanan (Egodawatta et al. 2009). Titik persampelan T3 mempunyai kepekatan TSS yang paling rendah berbanding T1 dan T2 kerana air tersebut telah ditapis dengan menggunakan penapis karbon dan juga batu kerikil. TSS kebiasaannya disebabkan oleh kemasukkan faktor luaran yang dibawa oleh air larian hujan yang boleh membantu meningkatkan kepekatan parameter ini (Jonnalagadda \& Mhere 2001; Suratman et al. 2006; Rossi et al. 2005).

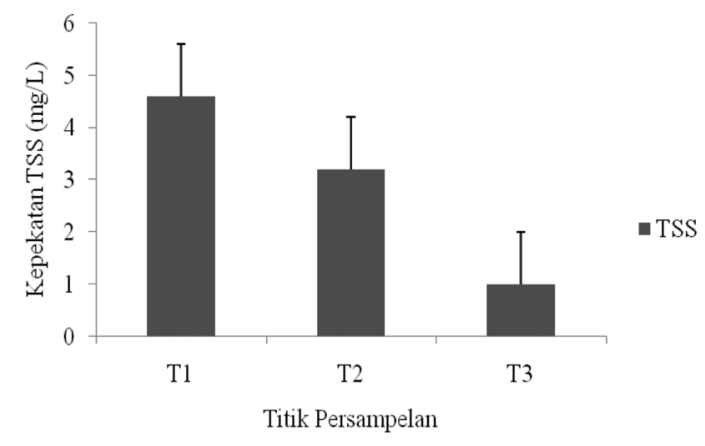

Bacaan dalam purata \pm sisihan piawai $(n=5)$

RAJAH 5. Purata nilai TSS bagi tiga titik persampelan
Rajah 6 pula menunjukkan graf bagi purata tahap kekeruhan di dalam air hujan. Hasil kajian mendapati bahawa tahap kekeruhan berada pada bawah nilai piawaian yang ditetapkan oleh KKM iaitu $1000 \mathrm{ntu}$. Titik persampelan T1 mempunyai nilai bacaan yang paling tinggi iaitu 3.06 ntu. Manakala T3 mempunyai nilai bacaan yang paling rendah iaitu $0.93 \mathrm{ntu}$. Hal ini disebabkan oleh faktor kepekatan TSS dalam air hujan akan mempengaruhi kejernihan air hujan tersebut. Semakin tinggi kandungan partikel di dalam air hujan, semakin banyak cahaya akan diserakkan (Yap et al. 2011). Air hujan pada titik persampelan T3 lebih jernih berbanding T1 dan T2. Nilai bacaan parameter kekeruhan bagi pelencong pancur pertama pada sistem MyRAWAS adalah hampir sama bacaan dengan hasil kajian Thamer et al. (2012) iaitu air hujan yang tidak rawat mempunyai nilai bacaan $3.97 \mathrm{ntu}$. Kekeruhan air disebabkan kehadiran pepejal terampai yang terdiri daripada bahan organik yang mengandungi mikroorganisma dan bahan bukan organik (Ithnin et al. 2012). Oleh itu, air yang keruh boleh memberikan keadaan yang sesuai untuk pertumbuhan mikroorganisma dalam SPAH.

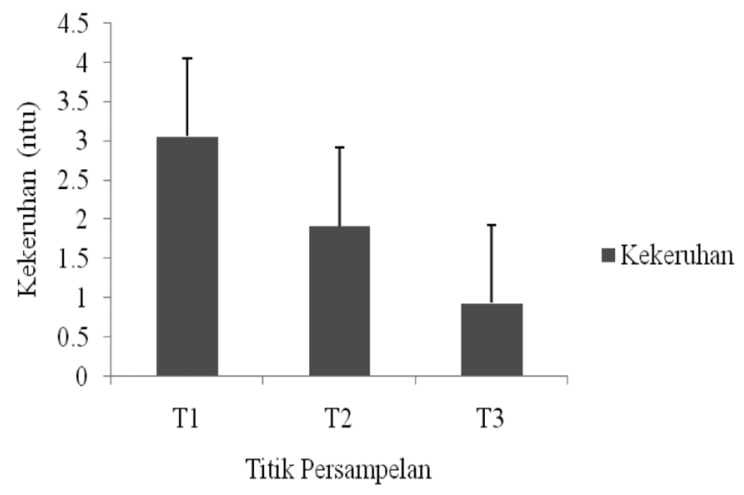

Bacaan dalam purata \pm sisihan piawai $(n=5)$

RAJAH 6. Purata nilai kekeruhan bagi tiga titik persampelan

Rajah 7 menunjukkan purata kepekatan Do bagi setiap titik persampelan. Berdasarkan rajah tersebut, titik persampelan T3 mempunyai nilai bacaan kepekatan DO yang lebih tinggi berbanding titik persampelan yang lain. Manakala bacaan kepekatan DO yang paling rendah adalah pada titik persampelan $\mathrm{T} 2$ iaitu pada tangki pengumpulan. Berdasarkan NWQS Malaysia, bacaan DO pada T1 dan T3 berada pada kelas I manakala bacaan DO pada T2 berada pada kelas II (EPA 2008). Dalam kajian yang dijalankan oleh Suratman dan Norhayati (2013), mendapati bahawa nilai bacaan DO pada sesuatu titik persampelan dipengaruhi oleh kepekatan TSS dengan kepekatan DO adalah berkadar songsang dengan kepekatan TSS. Ini disebabkan oleh proses pengoksidaan TSS menggunakan oksigen. Malah, dalam analisis korelasi yang didapati daripada kajian Suratman dan Norhayati (2013) juga mendapati terdapat hubungan yang sederhana kuat antara kepekatan DO dengan TSS. 


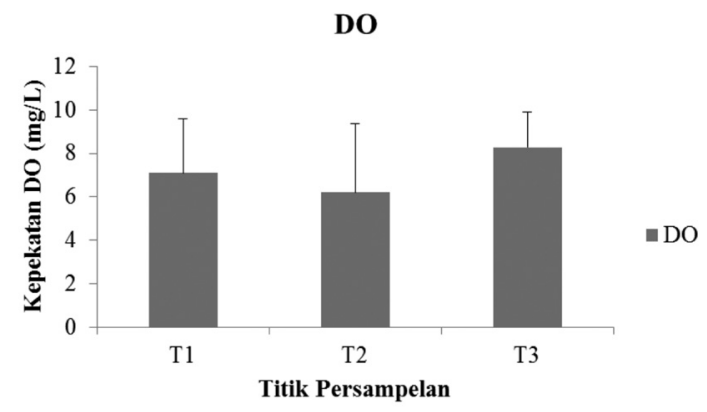

Bacaan dalam purata \pm sisihan piawai $(n=5)$

RAJAH 7. Purata nilai kepekatan DO bagi tiga titik persampelan

Rajah 8 menunjukkan hasil nilai purata bagi kepekatan BOD bagi ketiga-tiga titik persampelan. Kesemua titik persampelan mempunyai nilai bacaan tidak lebih daripada nilai piawaian yang dibenarkan oleh KKM iaitu $6 \mathrm{mg} / \mathrm{L}$ (KKM 2010) dan berada pada kelas I berdasarkan NWQS Malaysia (EPA 2008). Titik persampelan T2 mempunyai nilai bacaan yang paling tinggi berbanding titik persampelan yang lain iaitu dengan nilai bacaan sebanyak $0.70 \mathrm{mg} / \mathrm{L}$. Hal ini kerana, terdapatnya banyak bahan organik yang boleh diuraikan oleh sesuatu mikroorganisma dan proses ini memerlukan oksigen terlarut. Air hujan yang mengalir daripada bumbung bangunan akan membawa patogen mikrob daripada najis burung, tikus atau haiwan lain yang membuat sarang di atas bangunan (Lim \& Jiang 2013). Ini akan menyebabkan mikrob tersebut masuk ke dalam tangki pengumpulan dan akan menggunakan oksigen untuk menguraikan bahan organik. Menurut Suratman et al. (2015), kepekatan BOD menunjukkan jumlah oksigen terlarut yang digunakan untuk penguraian bahan organik oleh mikroorganisma. Malah, dalam kajian yang lepas mendapati bahawa kebarangkalian bagi bahan pencemar biologikal dan kimia pada air larian dari bumbung yang memasuki tangki air hujan adalah tinggi (Evans et al. 2006: Lye 2002; Spinks et al. 2003).

Berdasarkan Rajah 9, julat bacaan bagi parameter COD adalah di bawah paras nilai piawaian yang ditetapkan oleh KKM iaitu $10 \mathrm{mg} / \mathrm{L}$. Nilai bacaan COD yang tinggi direkodkan pada T1 dan T2. Bacaan kepekatan COD

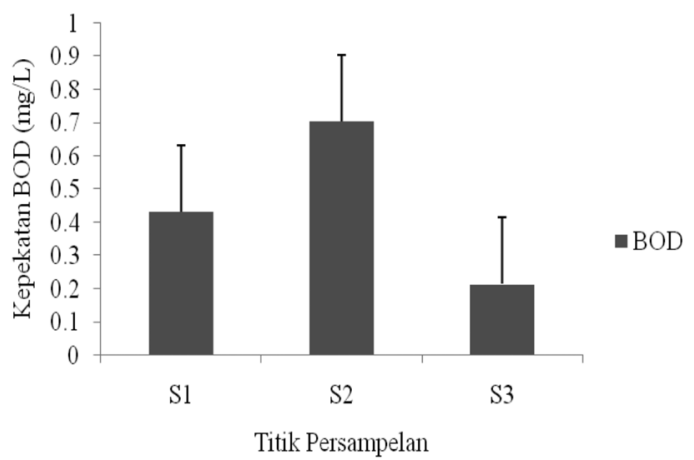

Bacaan dalam purata \pm sisihan piawai $(n=5)$

RAJAH 8. Purata nilai kepekatan BOD bagi tiga titik persampelan

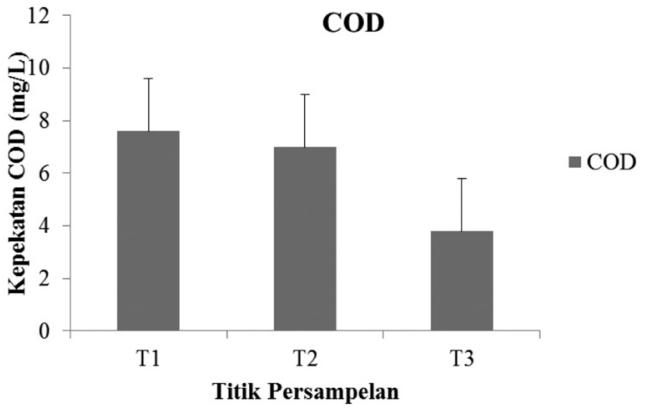

Bacaan dalam purata \pm sisihan piawai $(n=5)$

RAJAH 9. Purata nilai kepekatan COD bagi tiga titik persampelan

menurun daripada T1, T2 sehingga T3 iaitu masingmasing sebanyak 7.6, 7.0 dan $3.8 \mathrm{mg} / \mathrm{L}$. Semakin tinggi bacaan COD, semakin banyak oksigen yang digunakan bagi membantu dalam proses pengoksidaan bahan pencemar kimia. Pertambahan bacaan COD berlaku disebabkan oleh pertambahan pelbagai bahan organik yang dioksidakan secara kimia (Corwin et al. 2001). Melihat pada tahap kepekatan TSS, nilai bacaan yang tinggi juga direkodkan pada T1 dan T2. TSS mengandungi bahan organik dan bukan organik. Bahan organik dalam air menggunakan oksigen untuk proses pengoksidaan (Ithnin et al. 2012). Oleh itu, kepekatan TSS yang tinggi dikaitkan dengan bacaan COD yang tinggi. Justeru, penggunaan penapis karbon membantu dalam penyingkiran sebatian organik dengan penjerapan pada karbon aktif. Berbeza dengan kajian yang lepas yang dijalankan oleh Mas Rahayu et al. (2009) yang dijalankan di kawasan perumahan dan perindustrian Parit Raja, Johor, nilai bacaan COD berada pada julat daripada 5.3 sehingga $40.7 \mathrm{mg} / \mathrm{L}$ iaitu lebih tinggi dari bacaan yang diperoleh daripada air hujan MyRAWAS. Hal ini kerana, lokasi persampelan yang berbeza menjadi faktor yang boleh mempengaruhi bacaan COD (Mas Rahayu et al. 2009).

Hasil daripada analisis ammonia-nitrogen yang dijalankan menunjukkan bacaan pada T1 dan T2 adalah masing-masing 0.47 dan $0.43 \mathrm{mg} / \mathrm{L}$. Manakala bacaan T3 pula menunjukkan bacaan lebih rendah iaitu $0.01 \mathrm{mg} / \mathrm{L}$ dan ini boleh dilihat pada Rajah 10. Nilai ammonianitrogen bagi T1 dan T2 berada di kelas III berdasarkan NWQS Malaysia (EPA 2008). Selepas air hujan menjalani rawatan penapisan batu kerikil dan karbon teraktif, nilai ammonia-nitrogen di T3 telah turun kepada kelas I. Hal ini disebabkan oleh sistem penapisan iaitu karbon aktif yang boleh membantu mengurangkan kandungan ammonianitrogen dalam air hujan sebelum dimasukkan ke dalam tangki penyimpanan. Secara amnya, proses penjerapan telah berlaku kerana kesemua molekul akan menggunakan tenaga bagi bercantum dan melekat antara satu sama lain. Karbon teraktif mempunyai tapak permukaan yang luas dan pelbagai taburan saiz liang yang memberinya kelebihan untuk menyerap pencemar organik (Halim et al. 2010).

Bagi parameter mikrobiologi pula, ujian hidrogen sulfida $\left(\mathrm{H}_{2} \mathrm{~S}\right)$ telah digunakan sebagai indikator bagi 


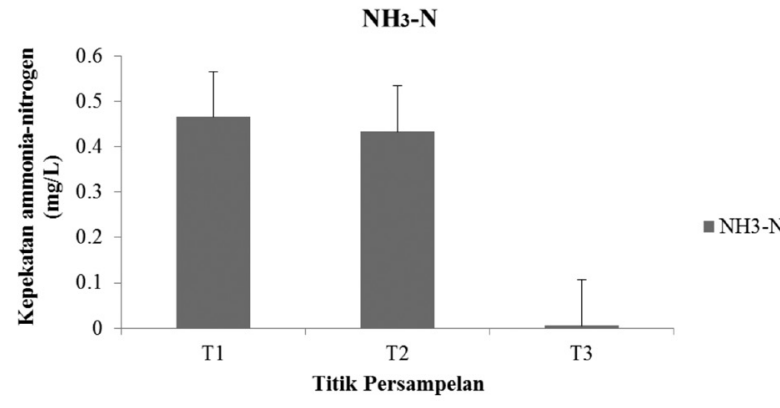

Bacaan dalam purata \pm sisihan piawai $(n=5)$

RAJAH 10. Purata nilai kepekatan ammonia-nitrogen bagi tiga titik persampelan

menentukan kehadiran bakteria enterik. Ujian ini telah dibuktikan bahawa ia mempunyai korelasi yang baik dengan jumlah koliform tahan haba dalam tangki air hujan (Faisst \& Fujioka 1994). Dalam ujian $\mathrm{H}_{2} \mathrm{~S}$ yang dijalankan, kesemua sampel yang diuji dalam botol $\mathrm{H}_{2} \mathrm{~S}$ bertukar daripada warna jernih kepada warna gelap selepas disimpan selama 24 jam. Ini menunjukkan berlakunya tindak balas oleh bakteria enterik tertentu yang akan menyebabkan pengurangan tiosulfat dan berlaku tindak balas dengan garam ferik bagi menghasilkan mendakan hitam iaitu ferrous sulfida tidak larut (Mosley \& Sharp 2005). Menurut Thamer et al. (2012), penggunaan bumbung sebagai tadahan air hujan kebiasaannya akan tercemar oleh mikrob yang terdiri daripada pelbagai bakteria penunjuk dan organisma patogen melainkan adanya rawatan khas semasa pengumpulan dan penyimpanan air hujan.

Hasil kajian bagi ujian Colilert bagi ketiga-tiga titik persampelan ditunjukkan pada Jadual 3 bagi parameter Koliform Jumlah dan Jadual 4 bagi parameter E. coli. Kesemua bacaan bagi Koliform Jumlah adalah di bawah nilai Piawai Air Minum Kebangsaan (KKM 2010) iaitu $5000 \mathrm{MPN} / 100 \mathrm{~mL}$ dan berada pada kelas I berdasarkan NWQS Malaysia (EPA 2008). Bacaan Koliform Jumlah pada titik persampelan T1 dan T2 menurun selepas melalui sistem rawatan penapisan iaitu daripada bacaan 7.48 MPN/100 mL (T1) dan 7.98 MPN/100 mL (T2) berkurang kepada 2.2 MPN/100 mL pada titik persampelan T3. Hal ini disebabkan oleh adanya sistem penapisan yang membantu dalam mengurangkan jumlah bakteria pada T3. Penggunaan sistem penapisan karbon aktif boleh membantu mengurang dan menghapuskan kebanyakan sebatian kimia organik, klorin, bakteria, plumbum, ferum dan radon (Macomber 2010). Secara amnya, kontaminasi mikrob hanya akan berlaku setelah bersentuhan dengan sesuatu permukaan misalnya bumbung bangunan (Olobaniyi \& Efe 2007). Kajian di negara lain seperti Jordan, Greece dan Mekong Delta, Vietnam mempunyai nilai bacaan Koliform Jumlah yang tinggi dan melebihi nilai piawaian yang ditetapkan oleh WHO (Abdullah \& Al-Shareef 2009; Gikas \& Tsihrintzis 2012; Wilbers et al. 2013). Hal ini kerana, penggunaan SPAH di negara tersebut tidak dilengkapi dengan sistem penapisan atau rawatan lain bagi merawat air tuaian hujan. Ketiadaan rawatan air hujan dan penyelenggaraan sistem yang secukupnya boleh menyebabkan pembiakan bakteria semakin meningkat (Sadia et al. 2014).

Kehadiran E. coli dalam sampel air berada pada tahap yang selamat dan mematuhi Nilai Piawai Air Minum Kebangsaan Malaysia. E. coli adalah merupakan salah satu bakteria penunjuk yang bersifat patogenik dan ia wujud di dalam najis manusia atau haiwan (Apraku \& Adu-Kumi 2014). Kehadiran E. coli di dalam sampel air adalah disebabkan oleh kotoran yang memasuki tangki melalui kawasan tadahan, atau dari bangkai binatang dan serangga, atau akibat aktiviti manusia di atas bumbung. Malah, kebanyakan kawasan tadahan jarang dibersihkan (Lee et al. 2010). Walau bagaimanapun, nilai E. coli pada sampel air hujan daripada MyRAWAS adalah rendah dan ia adalah selamat untuk diminum selepas air tersebut dimasak pada suhu $>70{ }^{\circ} \mathrm{C}$ (CDC 2016).

Selepas pengiraan IKA dilakukan, air hujan yang dituai sebelum ditapis berada pada kelas IIA (T1=89.92 dan $\mathrm{T} 2=86.81)$ dan bertukar kepada kelas I (T3=97.69) selepas melalui kaedah rawatan semula jadi. Ini menunjukkan air hujan di dalam tangki penyimpanan sesuai digunakan sebagai aktiviti selain daripada untuk diminum misalnya untuk kegunaan domestik.

JADUAL 3. Purata bacaan Koliform Jumlah pada ketiga-tiga titik persampelan

\begin{tabular}{lccc}
\hline & Titik persampelan T1 & Titik persampelan T2 & Titik persampelan T3 \\
\hline Bacaan koliform jumlah (MPN/100 mL) & 7.48 & 7.98 & 2.2 \\
Nilai piawaian (MPN/100 mL) & 5000 & 5000 & 5000 \\
\hline
\end{tabular}

JADUAL 4. Purata bacaan E. coli pada ketiga-tiga titik persampelan

\begin{tabular}{|c|c|c|c|}
\hline & Titik persampelan T1 & Titik persampelan $\mathrm{T} 2$ & Titik persampelan T3 \\
\hline $\begin{array}{l}\text { Bacaan E. coli } \\
(\mathrm{MPN} / 100 \mathrm{~mL})\end{array}$ & $<1$ & $<1$ & $<1$ \\
\hline $\begin{array}{l}\text { Nilai Piawaian Kualiti Air Minum Kebangsaan } \\
\text { (MPN/100 mL) }\end{array}$ & 5000 & 5000 & 5000 \\
\hline
\end{tabular}




\section{KESIMPULAN}

Kajian ini bertujuan menentukan kualiti air hujan daripada sistem penuaian air hujan (MyRAwAS) di Kolej Ungku Omar (KUO), UKM Bangi iaitu pada pelencong pancur pertama, tangki pengumpulan dan tangki penyimpanan. Air hujan tersebut dibandingkan dengan nilai piawaian yang telah ditetapkan oleh Jabatan Alam Sekitar (JAS) dan Kementerian Kesihatan Malaysia (KKM). Kesemua nilai bacaan yang diperoleh menepati nilai piawaian yang dibenarkan. Terdapat beberapa parameter yang mempunyai perbezaan yang signifikan di antara titik persampelan T1 (pelencong pancur pertama) dan T3 (tangki penyimpanan) iaitu parameter kekeruhan, TSS dan $\mathrm{NH}_{3}-\mathrm{N}$. Di samping itu, penggunaan sistem penapisan yang terdiri daripada karbon teraktif dan batu kerikil dapat meningkatkan kualiti air tersebut menjadi lebih baik. Ini dapat dibuktikan bahawa nilai bacaan sebelum air hujan dirawat yang berada pada kelas IIA berubah kepada kelas I selepas air hujan dirawat. Oleh yang demikian, air hujan daripada sistem MyRAWAS ini selamat digunakan untuk aktiviti harian pelajar seperti kegunaan domestik dan juga boleh digunakan sebagai air minuman dengan tambahan rawatan lanjutan terhadap air hujan yang dituai.

\section{PENGHARGAAN}

Setinggi-tinggi penghargaan ditujukan kepada kumpulan penyelidik Project Rainwater Harvesting System (TD-2014012) yang memberikan kebenaran untuk pengambilan sampel air hujan daripada Sistem MyRawas. Ucapan terima kasih juga kami ditujukan kepada Encik Mohd Rafie Lim Mohd Ros Lim, Encik Mohd Raizal Roslin dan Cik Flavia Longik untuk bantuan teknikal daripada segi penyediaan peralatan makmal dan pengendalian sampel kajian.

\section{RUJUKAN}

Abdullah, F.A. \& Al-Shareef, A.W. 2009. Roof rainwater harvesting systems for household water supply in Jordan. Desalination 243: 195-207.

Achadu, O.J.,Ako, F.E. \& Dalla,C.L. 2013. Quality assessment of stored harvested rainwater in Wukari, north-eastern Nigeria: Impact of storage media. IOSR J.Environ. Sci.Toxicol.Food Technol.7(5): 25-32.

APHA. 1999. Standard Methods for the Examination of Water and Wastewater. Ed. ke-20. Washington: American Public Health Association.

Apraku, A. \& Adu-Kumi, M. 2014. Sustainable development: Rainwater quality and safe use (A case study in Adukrom Akwapim). Int. J. Water Res. 2(1): 21-26.

CDC. 2016. Shiga Toxin-Producing E.coli \& Food Safety. http:// www.cdc.gov/features/ecoliinfection/index.html. Diakses pada 20 Oktober 2016.

Corwin, A.L., Larasati, R.P., Bangs, M.J., Wuryadi, S., Arjoso, S., Sukri, N.\& Porter, K.R. 2001. Epidemic dengue transmission in Southern Sumatra, Indonesia. Trans. R. Soc. Trop. Med. Hyg. 95(3): 257-265.

Egodawatta, P., Thomas, E. \& Goonetilleke, A. 2009. Understanding the physical processes of pollutant build- up and wash-off on roof surfaces. Sci. Total Environ. 407 : 1834-1841.

EPA. 2008. National Water Quality Standards for Malaysia. www.wepa-db.net/policies/law/malaysia/eq_surface.htm\#. Accessed on 16 September 2015.

Evans, C.A., Coombes, P.J. \& Dunstan, R.H. 2006. Wind, rain and bacteria: The effect of weather on the microbial composition of roof-harvested rainwater. Water Res. 40(1): 37-44.

Faisst, E.W. \& Fujioka, R.S. 1994. Assessment of Four Rainwater Catchment Designs on Cistern Water Quality. Dlm Proceedings of The 6th International Conference On Rainwater Catchment Systems, disunting oleh Bambrah, G.K., Otieno, F.O. \& Thomas, D.B. Nairobi, Kenya: International Rainwater Catchment Systems Association.

Gikas, D.G. \& Tsihrintzis, A.V. 2012. Assessment of water quality of first-flush roof runoff and harvested rainwater. J. Hydrol. 466-467: 115-126.

Halim, A.A., Aziz, H.A., Johari, M.A.M. \& Ariffin, K.S. 2010. Comparison study of ammonia and COD adsorption on zeolite, activated carbon and composite materials in landfill leachate treatment. Desalination 262: 31-35.

Ithnin, A., Awang, N., Fidaie, M., Halim, A.A. \& Mohd, R.A. 2012. Study on the effect of leachates from old dumping site on water quality of Sungai Batu in Taman Wahyu II, Selayang, Selangor. Glob. J. Environ. Res. 6(1): 22-29.

Jonnalagadda, S.B. \& Mhere, G. 2001. Water quality of the Odzi River in the Eastern Highlands of Zimbabwe. Water Res. 35: 2371-2376

Kasan, N.A. 2006. Kualiti air sungai berdasarkan analisis kimia dan kepelbagaian alga. Tesis Master. Universiti Teknologi Malaysia (tidak diterbitkan).

KKM. Drinking Water Quality Standard. 2010. http://kmam. moh.gov.my/publicuser/drinkingwaterqualitystandard.html. Diakses pada 16 September 2015.

Lee, J.Y., Yang, J.S., Han, M. \& Choi, J. 2010. Comparison of the microbiological and chemical characterization of harvested rainwater and reservoir water as alternative water resources. Sci. Total Environ. 408: 896-905.

Lee, K.E., Mokhtar, M., Hanafiah, M.M., Abdul Halim, A. \& Badusah, J. 2016. Rainwater harvesting as an alternative water resource in Malaysia: Potential, policies and development. J. Clean Prod. 126: 218-222.

Lim, K.Y. \& Jiang, S.C. 2013. Reevaluation of health risk benchmark for sustainable water practice through risk analysis of rooftop-harvested rainwater. Water Res. 47(20): 7273-7286.

Lye, D.J. 2002. Health risk associated with consumption of untreated water from household roof catchment systems. $J$. Am. Water Resour. Assoc. 38: 1301.

Macomber, P.S.H. 2010. Guidelines on Rainwater Catchment Systems for Hawaii. Hawaii. College of Tropical Agriculture and Human Resource Management.

Mas Rahayu Jalil, Mohd Hairul Khamidun, Sabariah Musa, Siti Nazahiyah Rahmat \& Zarina Md. Ali 2009. Chemical oxygen demand concentration and its spatial distribution for rainwater of a small area at Parit Raja, Batu Pahat, Johor, Malaysia. International Conference on Water Resources. Langkawi, Kedah. May 26-27.

Mosley, L.M. \& Sharp, D.S. 2005. The Hydrogen Sulphide (H2S) Paper-Strip Test. SOPAC Technical Report 373.

Olobaniyi, S.B. \& Efe, S.I. 2007. Comparative assessment of rainwater and groundwater quality in an oil producing area of 
Nigeria: Environmental and health implications. J. Environ. Health Res. 6(2): 111-118.

Rossi, L., Krejci, V., Rauch, W., Kreikenbaum, S., Fankhauser, R. \& Gujer, W. 2005. Stochastic modeling of total suspended solids (TSS) in urban areas during rain events. Water Res. 39: 4188-4196.

Sadia, R., Khan, M.T.R., Shatirah,A., Nazli, B.C.D., Biswas, S.K. \& Shirai, S.M. 2014. Sustainability of rainwater harvesting system in terms of water quality. Sci. World J. 2014: 1-10.

Salam, A. \& Mahmood, J.A. 1988. Studies on physico-chemical parameter of river system in Chitral, Pakistan. P. J. Zool. Abstract, Series No. 18.

Seong, Y.C. \& Sapari, N. 2003. Rainwater quality in Peninsular Malaysia. XI IRCSA Conference-Proceedings. Suruhanjaya Perkhidmatan Air Negara (SPAN)

Spinks, A.T., Coombes, P., Dunstan, R.H. \& Kuszera, G. 2003. Water quality treatment processes in domestic rainwater harvesting systems. Proceedings of the 28th International Hydrology and Water Resources Symposium. Wollongong, Australia.

Suratman, S. \& Norhayati, M.T. 2013. Kesan antropogenik terhadap kualiti air di lembangan Sungai Marang, perairan selatan Laut China Selatan. Sains Malaysiana 42(6): 743-751.

Suratman, S., Sailan, M.I.M., Hee, Y.Y., Bedurus, E.A. \& Latif, M.T. 2015. A Preliminary study of water quality index in Terengganu River Basin, Malaysia. Sains Malaysiana 44(1): 67-73.

Suratman, S., Mohd Tahir, N., Lee, C.Y. \& Siti Rohayu, A.R. 2006. Monsoon effects on water quality in Besut River basin, Terengganu. Malays. J. Anal. Sci. 10: 143-148.

Thamer, A.M., Megat, J.M.M.N. \& Abdul, H.G. 2012. Checking the adequacy of rainwater harvesting system for housing and landscaping. ALAM CIPTA, Intl. J. of Sustainable Tropical Design Research and Practice 2(1): 18-27.

United Nations World Water Assessment Programme (WWAP). 2015. The United Nations World Water Development Report 2015: Water for a Sustainable World. Paris: UNESCO.

Wilbers, G.J., Sebesvari, Z., Rechenburg, A. \& Renaud, F.G. 2013. Effects of local and spatial conditions on the quality of harvested rainwater in the Mekong Delta, Vietnam. Environ. Pollut. 182: 225-232.

World Health Organization (WHO)/ United Nations Children's Fund (UNICEF). 2014. Progress on Drinking Water and Sanitation. Switzerland.

Yap, C.K., Chee, M.W., Shamarina, S., Edward, F.B., Chew, W. \& Tan, S.G. 2011. Assessment of surface water quality in the Malaysian coastal waters by using multivariate analyses. Sains Malaysiana 40(10): 1053-1064.

Yaziz, M.I., Gunting, H., Sapari, N. \& Ghazali, A.W. 1989. Variations in rainwater quality from roof catchments. Wat. Res. 23(6): 761-765.

Nur Syarina Asman \& Farah Diyana Ariffin*

Program Kesihatan Persekitaran dan Keselamatan Industri

Pusat Pengajian Sains Diagnostik dan Kesihatan Gunaan

Fakulti Sains Kesihatan

Universiti Kebangsaan Malaysia

Jalan Raja Muda Abdul Aziz

50300 Kuala Lumpur, Wilayah Persekutuan

Malaysia

Azhar Abdul Halim \& Marlia Mohd Hanafiah

Pusat Pengajian Sains Sekitaran dan Sumber Alam

Fakulti Sains dan Teknologi

Universiti Kebangsaan Malaysia

43600 UKM Bangi, Selangor Darul Ehsan

Malaysia

*Pengarang untuk surat-menyurat; email: farahdiyana@ukm. edu.my

Diserahkan: 7 Jun 2016

Diterima: 27 Oktober 2016 